\title{
男性インポテンスに関する研究
}

\author{
第11報 ヒト陰茎血流動態の研究 \\ 東北大学医学部泌尿器科学教室 \\ （主任：折笠精一教授） \\ 助手 石 井 延 久

\section{STUDIES ON MALE SEXUAL IMPOTENCE. Report 11.} \\ Hemodynamic Mechanism of Erection in the Human Penis \\ Nobuhisa Ishii \\ Department of Urology, Tohoku University School of Medicine
}

For the purpose of analyzing intrapenial hemodynamics in connection with physiological erection, I performed experiments with $\mathrm{Xe}-133$ infused directly into the corpus cavernosum of 8 cases with no trouble on erection and ejaculation, and 40 cases with complaints of impotence. Its dissappearance rate was traced to obtain a declining curve showing Xe-133 clearance. In 47 of the 48 cases, a visual sexual stimulation (V.S.S.) was supplied to induce erection physiologically and changes in their Xe-133 curves were observed.

The curves of Xe-133 declined very gently at the time of non-erection in all 48 cases, with the intrapenial blood flow calculated from the curves ranging $0.5-6.5 \mathrm{ml} / 100 \mathrm{~g} / \mathrm{min}$, with a mean of $2.31 \mathrm{ml} / 100 \mathrm{~g} /$ min. Of the 47 cases receiving the V.S.S., the 21 with complete erections registered a marked fall in the Xe-133 curves after V.S.S., with the intrapenial blood flow increasing to $15.4-57.6 \mathrm{ml} / 100 \mathrm{~g} / \mathrm{min}$ (mean $31.61 \mathrm{ml} / 100 \mathrm{~g} / \mathrm{min}$ ). Also in the 13 cases with incomplete erection in response to the V.S.S., the Xe133 curves evidently fell, showing an increase in intrapenial blood flow after V.S.S., $5.8-16.4 \mathrm{ml} / 100 \mathrm{~g} /$ min (mean $11.90 \mathrm{ml} / 100 \mathrm{~g} / \mathrm{min}$ ). In the 13 cases with no sign of erection what so ever in response to the V.S.S., the Xe-133 curve and intrapenial blood flow before and after V.S.S. showed no evident change. These results have led us to conclude that human penial erection is not solely attributable to intrapenial blood stagnation, as evidenced by vigorous increases in blood in flow into the penis erection and accompanying increases in the outflow of blood from the penis as well. Our findings seem to indicate that physiologically, erection is possible independent of the blockage of venous return circulation.

\footnotetext{
緒 言

従来よりヒト陰茎の勃起に際して陰茎の静脈系の閉鎖 機構が重要な役割を演じていると考えられてきた。即ち Conti (1952)1) はヒト陰荎の詳細な解剖学的研究から， 陰茎には内腔を自由に变えることのできる構造をるつ動 脈, 静脈に加えて動静脈吻合が存在することを明らかに し,これら構造よりヒト陰茎の勃起のメカニズムを次の ように推論した。 それによると陰茎内の 血流は非勃起 時にはこの動静脈吻合を通り，海綿体内には流れなない が, 勃起時にはこの動静脈吻合が閉じて血抗は海綿体内 飞流れこみ,さらに陰茎海綿体よりの流出静脈も勃起時 そは内腔が閉じて，海綿体よりの流出を妨げることによ り勃起を促進すると説明している。
}

しかし, Newman (1964) はcadaver および volanteer の陰茎を用いた実験で, ある一定量以上の血流が海綿体 に流入すれば, 静脈系の閉鎖がなくとも十分に勃起は拉 こりらると述べており，いまだ意見の一致をみないのが 現状である.

そこで著者は勃起のメカニズム解明の一端として勃起 の際に陰茎内の静脈遷流系に収縮域は閉鎖機構が実際に 働くのか否かる検討してみた．即ち著者は肺を通過する と殆んど血中に残らない,つまり再循環が殆んど無視で きる放射性ガスである $\mathrm{Xe}-133$ 陰茎海綿体内に注入 し, その減衰曲線から非勃起時の陰茎内血流量 (正確に は院茎海綿体より流出する血流量）を測定すると同時に 視覚による性的刺激 visual sexual stimulation (V.S.S.) 
を患者に負荷することにより生理的な勃起をおこさせて その変化を観察した．また造影剤を陰茎海綿体内に注入 し, 勃起前後の造影剤の動態も合わせて観察し, ヒト陰 茎の勃起の際に陰茎の静脈系の閉鎖機構が関与するのか 否かを検討したのでその結果につき報告する。

\section{検査対象ならびに検查方法}

検查対象は第 1 表の如く29歳〜35歳までの勃起や射精 飞は全く問題のない尿路結石症 2 例および同様に勃起や 射精に何等支障のない男性不娃症 6 例の合計 8 例の正常 症例群と 18 歳 62歳までのインポテンスを主訴とした 40 例である。インポテンスを主訴とした症例の内訳は過去 に外傷等のインポテンスになるべき器質的要因の全く認 められない症例は19例で年齢は21歳〜50歳である。さら
第 1 表 検查対象

\begin{tabular}{l}
\hline 1. 正常症例群 \\
男性不娃症 \\
尿路結石症
\end{tabular}

に過去をたは現在に何らかの神経疾患や外傷等の器質的 要因の認められる症例は16例で，年齢は18歳～62歳まで の症例である (第 2，3，4 表).また過去に精神病と診 断治療された既往のある患者は 5 例で，年齢は 27 歳〜 48

第 2 表 (I) Complete Erection after V.S.S.

\begin{tabular}{|c|c|c|c|c|c|c|c|c|}
\hline \multirow{2}{*}{ No. } & \multirow{2}{*}{ Case } & \multirow{2}{*}{ Age } & \multirow{2}{*}{ Xe- 133} & \multicolumn{2}{|c|}{$\begin{array}{c}\text { Intrapenial } \\
\text { blood flow } \\
(\mathrm{ml} / 100 \mathrm{~g} / \mathrm{min})\end{array}$} & \multirow[t]{2}{*}{ Ratio } & \multirow{2}{*}{ Erection } & \multirow{2}{*}{ Remarks } \\
\hline & & & & $\begin{array}{l}\text { before } \\
\text { V.S.S. }\end{array}$ & $\begin{array}{l}\text { after } \\
\text { V.S.S. }\end{array}$ & & & \\
\hline 1 & K.M. & 27 & 120 & 0.96 & - & - & - & \\
\hline 2 & S. T. & 29 & 300 & 2.7 & 43.2 & 16.0 & complete & Control(Male sterility) \\
\hline 3 & M.K. & 33 & 200 & 2.2 & 42.0 & 21.0 & $"$ & " \\
\hline 4 & K. A. & 35 & 300 & 0.7 & 50.5 & 72.1 & $"$ & " \\
\hline 5 & T. K. & 34 & 300 & 3.0 & 21.5 & 7.2 & " & " \\
\hline 6 & T.M. & 32 & 300 & 1.4 & 57.6 & 41.0 & " & " \\
\hline 7 & T.S. & 29 & 200 & 4.1 & 20.4 & 5.0 & $"$ & $\begin{array}{l}\text { Non organic factor of } \\
\text { sexual impotence }\end{array}$ \\
\hline 8 & K. K. & 27 & 300 & 1.0 & 47.0 & 47.0 & $"$ & " \\
\hline 9 & T.K. & 29 & 300 & 3.6 & 19.8 & 5.4 & $"$ & " \\
\hline 10 & K. S. & 42 & 200 & 0.4 & 23.3 & 58.3 & " & " \\
\hline 11 & Y.A. & 22 & 170 & 1.5 & 24.8 & 16.5 & $"$ & " \\
\hline 12 & I. W. & 45 & 170 & 0.5 & 47.3 & 94.6 & $"$ & " \\
\hline 13 & K. T. & 21 & 125 & 1.3 & 23.1 & 17.8 & " & " \\
\hline 14 & ${ }^{*} \mathrm{~K} . \mathrm{T}$. & 26 & 300 & 1.4 & 24.5 & 17.5 & " & $"$ \\
\hline 15 & T. C. & 26 & 250 & 3.8 & 20.4 & 5.4 & " & " \\
\hline 16 & Y.K. & 50 & 200 & 2.6 & 26.1 & 10.0 & " & " \\
\hline 17 & K. T. & 25 & 300 & 4.6 & 34.8 & 7.6 & " & " \\
\hline 18 & K. S. & 34 & 300 & 0.7 & 42.9 & 61.3 & " & Shizophrenia \\
\hline 19 & T. D. & 42 & 240 & 3.9 & 28.9 & 7.4 & $"$ & Depression \\
\hline 20 & K. S. & 29 & 125 & 0.9 & 20.2 & 22.4 & " & Shizophrenia \\
\hline 21 & K. S. & 54 & 200 & 3.2 & 30.1 & 9.4 & " & $\begin{array}{l}\text { Hernia of interverte- } \\
\text { bral disc (non ope.) }\end{array}$ \\
\hline 22 & ${ }^{*}$ M.S. & 32 & 300 & 2.3 & 15.4 & 6.7 & " & $\begin{array}{l}\text { Control } \\
\text { (Ureterolithiasis) }\end{array}$ \\
\hline \multicolumn{2}{|c|}{ Mean } & 32.9 & & 2.13 & 31.61 & 26.17 & & \\
\hline
\end{tabular}


第 3 表 (II) Incomplete Erection after V.S.Sr

\begin{tabular}{|c|c|c|c|c|c|c|c|c|}
\hline \multirow{2}{*}{ No. } & \multirow{2}{*}{ Case } & \multirow{2}{*}{ Age } & \multirow{2}{*}{ Xe- 133} & \multicolumn{2}{|c|}{$\begin{array}{c}\text { Intrapenial } \\
\text { blood flow } \\
\text { (ml } / 100 \mathrm{~g} / \mathrm{min}) \\
\end{array}$} & \multirow{2}{*}{ Ratio } & \multirow{2}{*}{ Erection } & \multirow{2}{*}{ Remarks } \\
\hline & & & & $\begin{array}{l}\text { before } \\
\text { V.S.S. }\end{array}$ & $\begin{array}{l}\text { after } \\
\text { V.S.S. }\end{array}$ & & & \\
\hline 23 & S.S. & 33 & 300 & 0.5 & 9.9 & 19.8 & $\begin{array}{l}\text { in- } \\
\text { complete }\end{array}$ & $\begin{array}{l}\text { Control } \\
\text { (Male sterility) }\end{array}$ \\
\hline 24 & ${ }^{*} \mathrm{H} . \mathrm{K}$. & 35 & 300 & 2.5 & 10.7 & 4.3 & " & $\begin{array}{l}\text { Control } \\
\text { (Ureterolithiasis) }\end{array}$ \\
\hline 25 & ${ }^{*} \mathrm{~K} . \mathrm{M}$. & 24 & 200 & 1.8 & 12.2 & 6.8 & $"$ & $\begin{array}{l}\text { Non organic factor of } \\
\text { sexual impotence }\end{array}$ \\
\hline 26 & T.K. & 28 & 200 & 3.3 & 14.4 & 4.4 & " & " \\
\hline 27 & K. U. & 23 & 500 & 1.2 & 16.4 & 13.7 & " & 11 \\
\hline 28 & M.K. & 26 & 120 & 5.8 & 15.4 & 2.7 & " & " \\
\hline 29 & K. I. & 26 & 120 & 0.7 & 5.1 & 10.2 & $"$ & " \\
\hline 30 & $\mathrm{~K} . \mathrm{T}$. & 48 & 180 & 0.5 & 14.1 & 28.2 & $"$ & Depression \\
\hline 31 & Y.K. & 27 & 170 & 1.1 & 14.1 & 12.8 & " & Shizophrenia \\
\hline 32 & *T.T. & 19 & 200 & 1.3 & 13.9 & 10.7 & $"$ & Acute Myelitis \\
\hline 33 & *H. A. & 18 & 300 & 1.0 & 14.0 & 14.4 & $"$ & $\begin{array}{l}\text { Urethral rupture, } \mathrm{Fr} \text { - } \\
\text { acture of the pelvis }\end{array}$ \\
\hline 34 & T.O. & 59 & 300 & 1.0 & 8.7 & 8.7 & $"$ & Diabetes Mellitus \\
\hline 35 & N.K. & 62 & 300 & 0.8 & 5.8 & 7.3 & $"$ & $\begin{array}{l}\text { Hernia of interverte- } \\
\text { bral disc (non ope.) }\end{array}$ \\
\hline \multicolumn{2}{|c|}{ Mean } & 32.92 & & 1.65 & 11.90 & 11.08 & & \\
\hline
\end{tabular}

第 4 表 (III) Non Erection after V.S.S.

\begin{tabular}{|c|c|c|c|c|c|c|c|c|}
\hline \multirow[t]{2}{*}{ No. } & \multirow[t]{2}{*}{ Case } & \multirow{2}{*}{ Age } & \multirow[t]{2}{*}{ Xe- 133} & \multicolumn{2}{|c|}{$\begin{array}{c}\text { Intrapenial } \\
\text { blood flow } \\
(\mathrm{ml} / 100 \mathrm{~g} / \mathrm{min})\end{array}$} & \multirow[t]{2}{*}{ Ratio } & \multirow[t]{2}{*}{ Erection } & \multirow[t]{2}{*}{ Remiarks } \\
\hline & & & & $\begin{array}{l}\text { before } \\
\text { V.S.S. }\end{array}$ & $\begin{array}{l}\text { after } \\
\text { V.S.S. }\end{array}$ & & & \\
\hline 36 & M.A. & 32 & 180 & 2.8 & 3.3 & 1.2 & $(-)$ & $\begin{array}{l}\text { Urethral rupture } \\
\text { Fracture of the pelvis }\end{array}$ \\
\hline 37 & M.S. & 62 & 200 & 0.7 & 2.9 & 4.1 & $(-)$ & Traffic accident \\
\hline 38 & M.O. & 50 & 200 & 1.2 & 2.7 & 2.3 & $(-)$ & $\begin{array}{l}\text { Urethral rupture } \\
\text { Fracture of the pelvis }\end{array}$ \\
\hline 39 & K. S. & 34 & 300 & 4.2 & 7.7 & 1.8 & $(-)$ & $\begin{array}{l}\text { Urethral rupture } \\
\text { Fracture of the pelvis }\end{array}$ \\
\hline 40 & M.K. & 42 & 180 & 3.8 & 8.7 & 2.3 & $(-)$ & Whiplash injury \\
\hline 41 & S. I. & $* 49$ & 300 & 0.9 & 5.2 & 5.8 & $(-)$ & Urethral rupture \\
\hline 42 & A. 0 . & $* 49$ & 300 & 6.3 & 7.7 & 1.2 & $(-)$ & $\begin{array}{l}\text { Non organic factor of } \\
\text { sexual impotence }\end{array}$ \\
\hline 43 & T.N. & $* 41$ & 200 & 2.0 & 6.6 & 3.3 & $(-)$ & Urethral rupture \\
\hline 44 & S. K. & $* 44$ & 170 & 6.5 & 9.9 & 1.5 & $(-)$ & \begin{tabular}{|l|}
$\begin{array}{l}\text { Non organic factor of } \\
\text { sexual impotence }\end{array}$ \\
\end{tabular} \\
\hline 45 & M. K. & $* 45$ & 300 & 5.8 & 6.5 & 1.1 & $(-)$ & Spinal cord injury (L) \\
\hline 46 & E. N. & 59 & 340 & 0.5 & 3.8 & 7.6 & $(-)$ & $\begin{array}{l}\text { Contusion of the } \\
\text { pelvis }\end{array}$ \\
\hline 47 & N. A. & 27 & 120 & 3.3 & 3.9 & 1.1 & $(-)$ & $\begin{array}{l}\text { Epilepsy, Traffic } \\
\text { accident }\end{array}$ \\
\hline 48 & H. A. & 58 & 300 & 4.2 & 6.0 & 1.4 & $(-)$ & Post prostatectomy \\
\hline \multicolumn{2}{|c|}{ Mean } & 45.5 & & 3.25 & 5.76 & 2.67 & & \\
\hline
\end{tabular}


歳である。

検查方法は一般にレノグラムに使用されている日立 4 チャンネル動態記録装置 (Na 1 (Tl) crystal $2^{\prime \prime} \phi \times 22^{\prime \prime} 1$ ) を使用し，一部の症例（第 $2 \sim 4$ 表の*のついた症例） は東芝 $\gamma$ ーカメラ，レノグラムニニット， $\phi$ ディテクタ ー11インチを使用した。 またコリメーターは陰茎の勃起 による変化を考え十分幅広いものを使用した。検查手技 は患者を仰臥位にし，陰茎体部側面皮膚に局所麻醉を行 い, No. 20 の細い注射針を用いて Xe-133を陰茎海綿体 内に注入した。な和局所麻酔剤の勃起に対する影響が 考兄られたので一部の症例には十分な検查の説明を行な い。局所麻酔剤の使用を避けて Xe-133の注入を行なつ たが両者の間には差はないことを確認している。

$\mathrm{Xe}-133$ は科研化学社製 マルチドースシリンジ $10 \mathrm{mCi} /$ $10 \mathrm{ml}$ を使用し。その投与量は $120 \sim 500 \mu \mathrm{Ci}$ である。ま たコリメーターは陰茎より $10 \mathrm{~cm}$ 前後 $(5 \sim 15 \mathrm{~cm}$ の距 離）の距離に打いて測定するようにした。まず非勃起時 の陰茎内の $\mathrm{Xe}-133$ 減衰曲線を10分前後記録し，さらに 患者に視覚による性的刺激 (V.S.S.) を与兄, 減衰曲線 の変化を記録した。次に，Xe-133減衰曲線から陰茎内 血流量の計算法は田中 $(1972)^{3)}$ の方法に従つた. すなわ ち Xe-133減衰曲線を半対数用紙書きな打し, Xe-133 が半減するまでの時間 $\left(\mathrm{T}_{1} / 2\right)$ を求め, 陰茎組織 $100 \mathrm{~g}$ あたりの毎分の血流量 (B.F.) を求めた。計算式は第 1

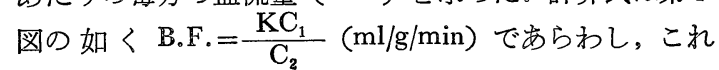
を100倍した。

な拈 $\mathrm{C}_{1}$ は組織血液間の 分配係数であるが，こ机は Xe-133を陰茎海綿体洞に直接注入することから陰茎海 綿体を1つの大きな血管と考えて 1 とした。 $\mathrm{C}_{2}$ は組織 の比重であるが陰茎も他の組織と同様に便宣上 1 と考兄 て計算した。 Kは disappearance constant であり。 one exponential curve では $\mathrm{K}=\log 2 / \mathrm{T}_{1} / 2$, two exponential curve では $\mathrm{K}=\frac{\mathrm{AK}_{1}+\mathrm{BK}_{2}}{\mathrm{~A}+\mathrm{B}}$, 但し $\mathrm{K}_{1}, \mathrm{~K}_{2}$ は各々の曲 線の disapearance constant A, B は各々の曲線が $\mathrm{Y}$ 軸を 切る值である。

最後に今回の検査対象で V.S.S。により完全勃起がみ られた症例のうち症例10，症例18の 2 例に対して陰茎海

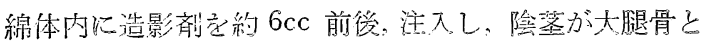
平行に造影されるように斜位をとり，非勃起時と勃起前 後の造影剤の動態を各々の症例について観察した。な和 造影剤は60\%コンレイを使用した。

\section{検查結果}

今回対象となつた 48 例の検查成績は第 $2 ， 3 ， 4$ 表に
第 1 図 陰茎内血流量の計算方法（田中：1972より 引用）

$$
\begin{aligned}
& \text { Blood flow }(B . F .) \mathrm{m} / \mathrm{g} / \mathrm{min}=\frac{\mathrm{KC}_{1}}{\mathrm{C}_{2}} \\
& \mathrm{~K}: \text { disapearance rate constant }
\end{aligned}
$$

a) one exponential curve

$$
K=\log 2 / T^{1} / 2
$$

b) two exp. curve

$$
\begin{gathered}
K=\frac{A K_{1}+B K_{2}}{A+B} \\
K_{1}=\log 2 / T_{1} 1 / 2 \quad K_{2}=\log 2 / T_{2} 1 / 2
\end{gathered}
$$

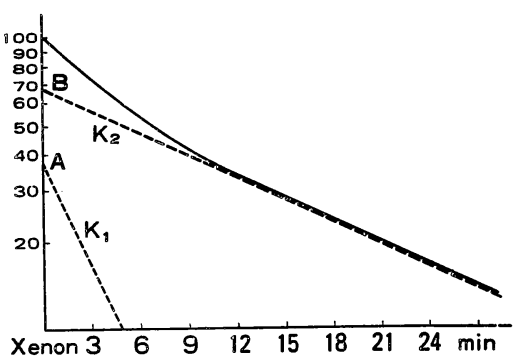

示した。

症例 1 の非勃起時の Xe-133減衰曲線は第 2 図に示す 如くである. 即ち, Xe-133注入後陰茎海綿体内に Xe133が拡散するのに要すると考学られる比較的平担な曲 線を示す部分（第 2 図のAに相当する部分）があり，そ の後はゆるやかな傾斜（第 2 図のBに相当する部分）を 示している。さらにこの Xe-133減衰曲線を半対数用紙 に書きな抢し，第 1 図の計算式にあてはめて，陰茎内血 流量を計算してみると陰茎組織100g あたりの每分の 血

第 2 図非勃起時の Xe-133減衰曲線（症例 1)

V.S.S. 負荷は行っていない。

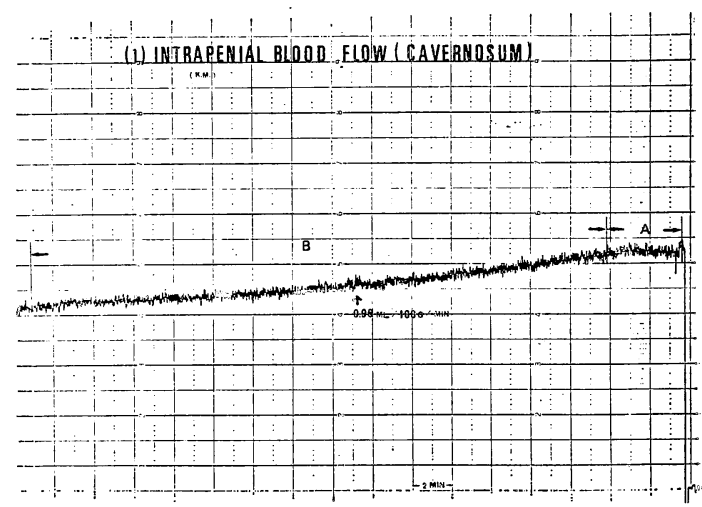


第 3 図 V.S.S. 負荷により完全な勃起のみられた症 例の Xe-133減衰曲線 (症例13)

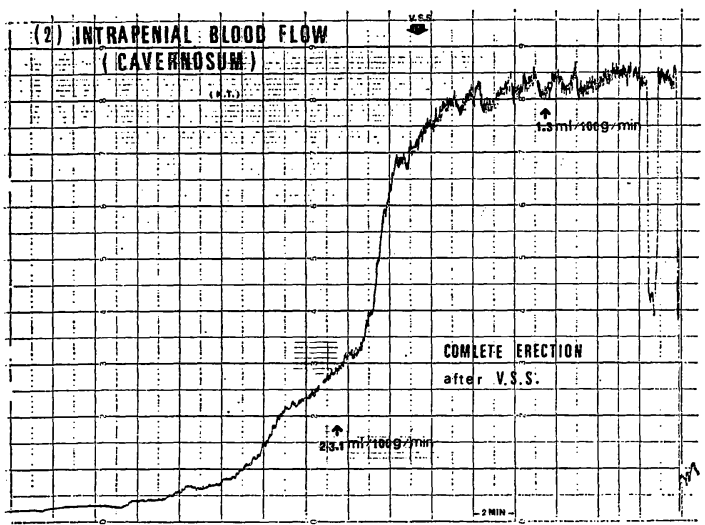

流量は $0.96 \mathrm{ml} / 100 \mathrm{~g} / \mathrm{min}$ であつた。また他の47例につい $\tau$ V.S.S. 負荷前の非勃起時の陰茎内血流量を同様にし て計算してみると0.5〜 $6.5 \mathrm{ml} / 100 \mathrm{~g} / \mathrm{min}$ であり, 症例 1 む含めて 48 例中16例 が $1.0 \mathrm{ml} / 100 \mathrm{~g} / \mathrm{min}$ 以下であつた. さらに10例が $1.1 \sim 2.0 \mathrm{ml} / 100 \mathrm{~g} / \mathrm{min}$ で, 48例中の非勃起 時の陰茎内血流量は $2.0 \mathrm{ml} / 100 \mathrm{~g} / \mathrm{min}$ 以下で 全症例の 平 均值は $2.30 \mathrm{ml} / 100 \mathrm{~g} / \mathrm{min}$ とかなりゆるやかな血流量であ ることがわかつた．次に V.S.S.を負荷した47例につい てみると, V.S.S. 負荷によりほぼ完全な勃起がみられた 21例(第 2 表 : 症例 2 22) の Xe-133減衰曲線はいずれ の症例も第 3 図（症例13）の如く勃起開始と同時に急激 な下降がみられた。これらの症例の陰茎内血流量をみる 之, 非勃起時は0.4 4.6ml $/ 100 \mathrm{~g} / \mathrm{min}$, 平均 $2.13 \mathrm{ml} / 100 \mathrm{~g} /$

第 4 図 V.S.S. 負荷に対して不完全な勃起のみられ た症例の Xe-133減衰曲線（症例23）

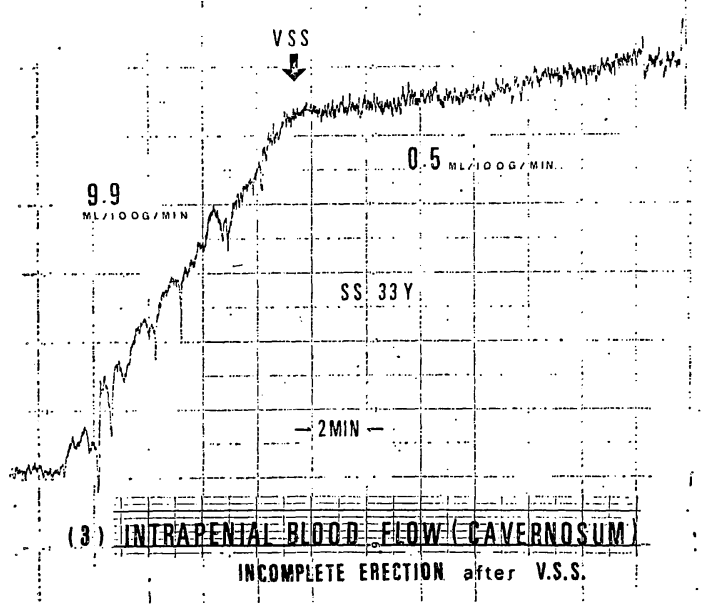

$\min$ で勃起時は15.4 $57.6 \mathrm{ml} / 100 \mathrm{~g} / \mathrm{min}$, 平均 $31.61 \mathrm{ml} /$ $100 \mathrm{~g} / \mathrm{min}$ と非勃起時の陰茎内血流量に比較すると, 5.0 94.6倍, 平均26.17倍の急激な陰茎内血流量の増加 を示している. 次に V.S.S. 負荷により勃起が不完全で あつた13例（第 3 表 : 症例23〜35）の Xe-133減衰曲線 は完全勃起のみられた 症例群程著明ではないが第 4 図 (症例23) の如く勃起と同時に Xe-133減衰曲線の下降 がみられている.この不完全な勃起のみられた13例の陰 茎内血流量をみると非勃起時は0.5 $5.8 \mathrm{ml} / 100 \mathrm{~g} / \mathrm{min}$, 平 均 $1.65 \mathrm{ml} / 100 \mathrm{~g} / \mathrm{min}$ で, V.S.S. 負荷後は5.1〜16.4ml/ $100 \mathrm{~g} / \mathrm{min}$, 平均 $11.90 \mathrm{ml} / 100 \mathrm{~g} / \mathrm{min}$ と勃起前と比較して 2.7〜28.2倍, 平均11.08倍の增加を示した. 以上のよう に多少でも V.S.S. 負荷により勃起とのみられた症例で

第 5 図 V.S.S. 負荷により全く勃起のみられなかつ た症例 Xe-133減衰曲線（症例36）

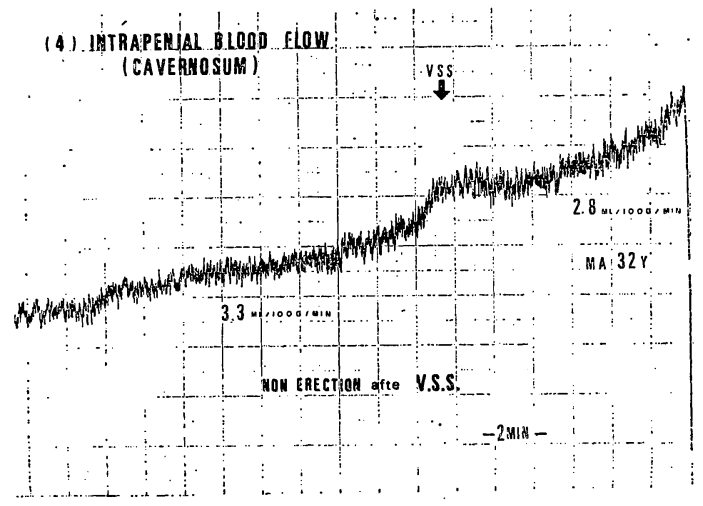

第 6 図 V.S.S. 負荷前後の陰茎内血流量の変化

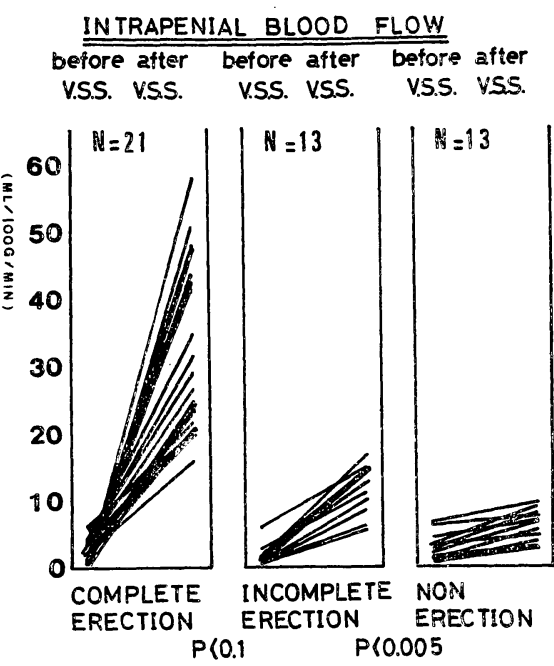


第 7 図 陰茎海綿体造影（症例10）

第 7 図(a) 造影剤注入直後直後

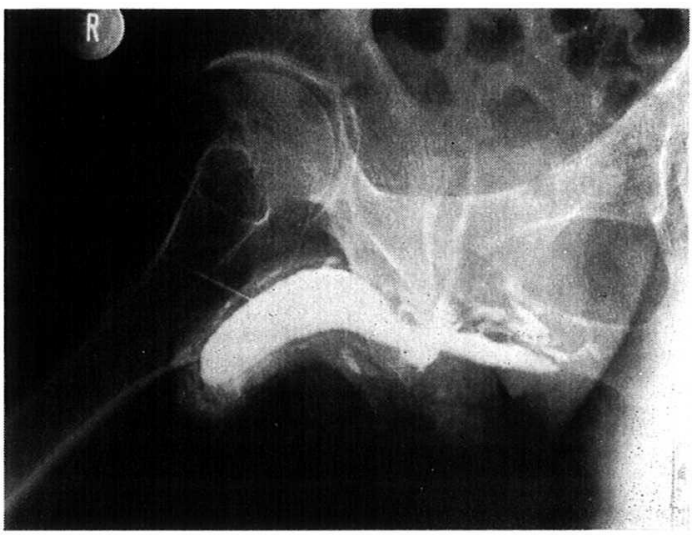

第 7 図(b) 造影剤注入後 5 分

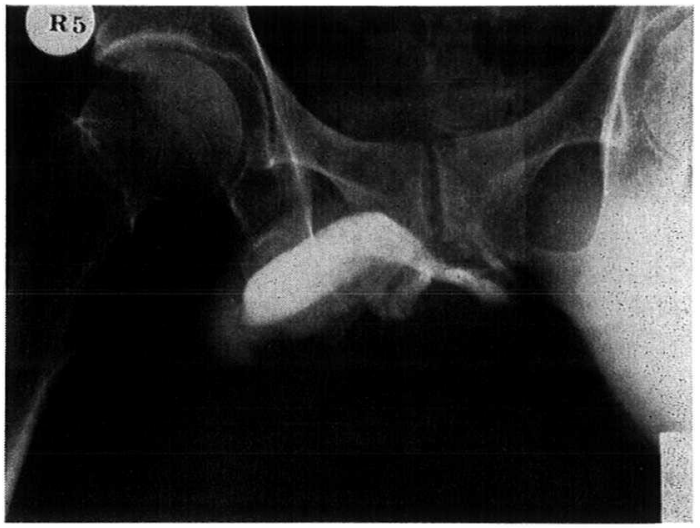

第 7 図(c) 造影剤注入後 10 分

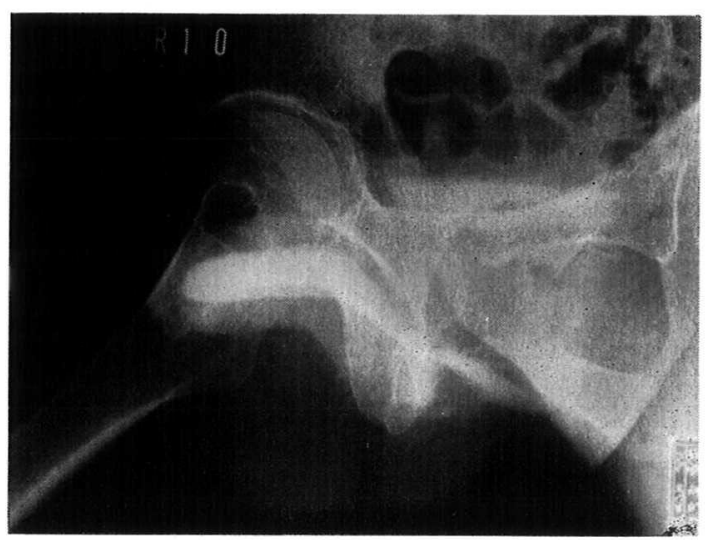

第 8 図 陰茎海綿体造影（症例18）

第 8 図(a) 造影剤注入直後

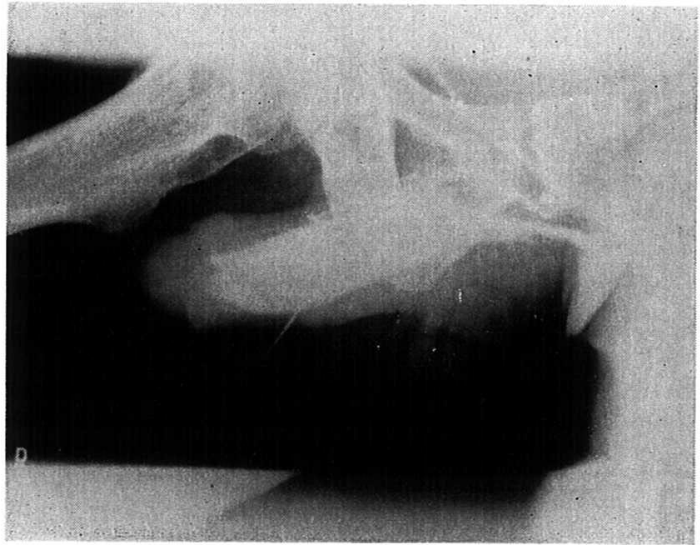

第 8 図(b) 造影剤注入後 2 分

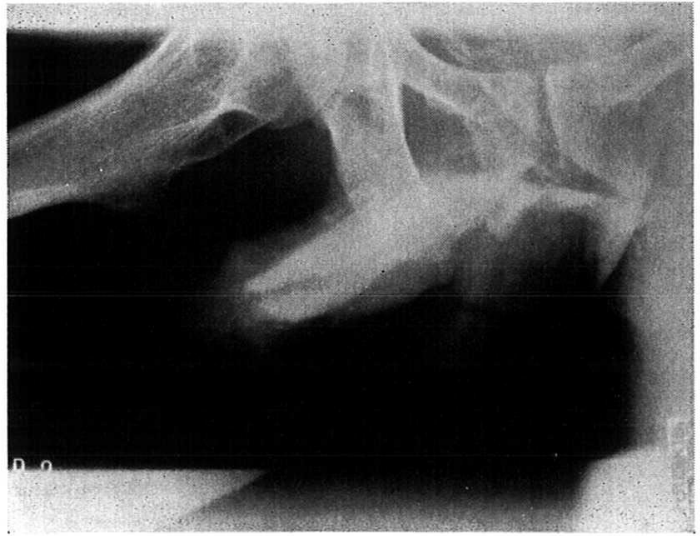

第 8 図(c) V.S.S. 負荷後 1 分 (造影剤注入後 4 分).

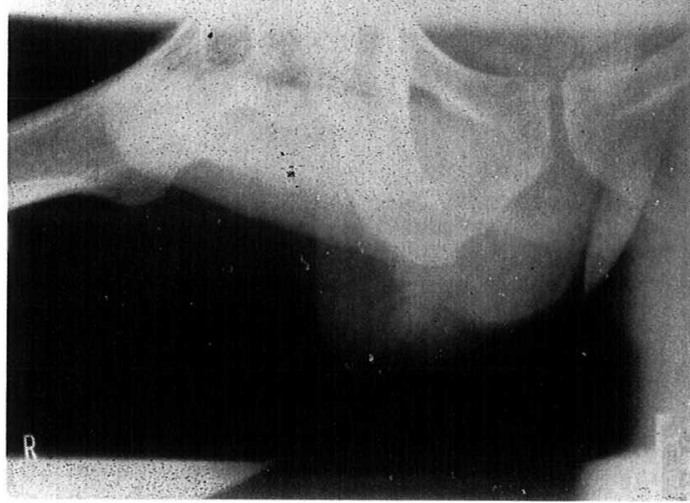


は全例とも勃起と同時に陰茎内の Xe-133は急激に陰茎 外に流出してしまうことがわかつた，最後に，V.S.S. 負 荷により全く勃起のみられなかつた13例（第 4 表：症例 36 48）の Xe-133減衰曲線は第 5 図（症例36）の如く V.S.S。負荷により殆ど変化はみられなかつた。しかし， 第 4 表の如く各症例の V.S.S。負荷後の陰茎内血流量の 変化をみると全例わずかながら V.S.S。負荷前に比較し て血流の増加をみている。即ち V.S.S. 負荷前が0.5 $6.5 \mathrm{ml} / 100 \mathrm{~g} / \mathrm{min}$, 平均 $3.25 \mathrm{ml} / 100 \mathrm{~g} / \mathrm{min}$ であつたもの が，V.S.S. 負荷後は $2.7 \sim 9.9 \mathrm{ml} / 100 \mathrm{~g} / \mathrm{min}$ ，平均 5.76 $\mathrm{ml} / 100 \mathrm{~g} / \mathrm{min}$ と1.1〜 7.6倍，平均2.67倍の血流増加を示 した。以上の結果を第 6 図のようにまとめて，完全勃起 のみられた症例群, 不完全勃起症例群, 全く勃起のみら れなかつた症例群を各々比較してみると, 完全勃起のみ られた症例群は 1 例を除きいずれの症例も勃起時の陰茎 内血流量は $20 \mathrm{ml} / 100 \mathrm{~g} / \mathrm{min}$ 以上の血流がみられている。 しかし勃起の不完全な症例や全く勃起のみられない症例 では 1 例も V.S.S。負荷後 $20 \mathrm{ml} / 100 \mathrm{~g} / \mathrm{min}$ 以上の陰茎内 血流量を示した症例はみられなかつた。次に V.S.S. 負 荷前後の陰茎内血流量の増加率をみると第 6 図の如く完 全な勃起のみられた21例では V.S.S. 負荷前に比較して V.S.S。負荷後は平均26.17倍の血流増加がみられ，不完 全な勃起であつた13例の平均11.08倍の 血流增加率 とは 有意の差はみられなかつた。しかし，これら勃起のみら れた症例群と全く勃起のみられなかつた13例の V.S.S。 負荷後の血流増加（平均2.67倍）の間には有意の差がみ られている。

一方以上述べた Xe-133による検査結果が正しいか否 かを巨視的に確める目的で陰茥海綿体内に造影剂を注入 してその動態をレントゲンテレビにて観察した。まず症 例10に対して造影剂 $6 \mathrm{ml}$ を陰茎海綿体内に注入し（第 7 図 (a)) 観察した. その結果造影剤注入後 5 分経過し ても造影剂は注入直後と殆ど大きな変化はみられず（第 7 図 (b))，さらに10分以上経過しても造影剂は陰茎海綿 体に殆ど残つていることがわかつた（第7図 (c)). 次に 症例18に対して造影剤注入後 2 分で V.S.S。負荷したと ころ，明らかな勃起による陰茎の腫脹とともに造影剤は 速やかに陰茎海綿体外一流出してしまらことがわかつた (第 8 図 (c)) これらの結果は Xe-133の検查成績とよく 一致した。

\section{考按}

従来。勃起のょカニズムに開する研究は七ト以外の動 物についてのものが大半であり。従つて解剖学的にも生
理学的にも全く異なる他の動物の実験結果がそのまま七 ト陰茎の場合にあてはまるか否か大変疑問である。一方 ヒト陰茎についての研究は極めて少く、しかもその殆ど が解剖学的研究であるためヒト陰茎の場合, 勃起のメカ ニズムの研究成果はあくまで推論の域をでないるのであ つた. そのため著者はヒト陰茎の勃起に際して従来, 考えられていたような陰茎の静脈遷流系の閉鎖機構が 㗢くのか否かについて実際に Xe-133を用いて検索し てみた。 Xe-133は殆えぞ化学的活性がなくかつ拡散性 の radioisotope で 1 回の肺循環で $95 \%$ 以上が肺胞から気 体として放出されてしまらので再循環が無視できるとこ ろから従来より脳。腎, 肝等の諸臓器や筋肉, 腫瘍の血 流測定に広く応用されてきた。そこでこの Xe-133を陰 茎海綿体内に注入してその減衰曲線より陰茎内の血流動 態を検討した。もし従来考兄られていたように勃起時陰 茎海綿体の静脈遷流系に閉鎖ないし狭窄が㧍こるとすれ ば，陰茎海綿体内に注入された Xe-133の減衰曲線は非 勃起時に比較してむしろゆるやかな曲線を示すはずであ る。しかし今回得られた結果は全くこれとは逆で非勃起 時の Xe-133減衰曲線はは非常にゆるやかであつたもの が V.S.S。負荷によりほぼ完全な勃起の認められた症例 では Xe-133減衰曲線はむしろ急激な下降が認められ た。これは明らかに勃起時に陰茎よりの遷流する血流量 が増加していることを示して怙り，勃起により陰茎の静 脈系に閉鎖ないし狭窄がおこつているとは考光にくい結 果であつた。

次に V.S.S. 負荷前後の陰茎 $100 \mathrm{~g}$ あたりの毎分の血 流量を計算してみたところまず V.S.S. 負荷前, 即ち非 勃起時の陰茎内血流量は $0.5 \sim 6.5 \mathrm{ml} / 100 \mathrm{~g} / \mathrm{min}$, 平均 2.31 $\mathrm{ml} / 100 \mathrm{~g} / \mathrm{min}$ であつた。このように非勃起時の血流量は極 めてゆるやかであり，このことは著者が陰茎海綿体造影 を执こなつて非勃起時に造影剂が海綿体内にかなり長時 間残つているといら事実とよく一致を示するのである。

次に V.S.S。負荷によりほぼ完全な勃起のみられた症 例ではいずれも陰茎内血流量の急激な増加がみられてい る。これら完全勃起のみられた症例の勃起時の陰茎 $100 \mathrm{~g}$ 两たりの毎分の血流量 は 1 例を除くと全例 $20 \mathrm{ml} / 100 \mathrm{~g} /$ min 以上の血流量であつた。また不完全な勃起を示した 症例では殆んどの症例の Xe-133減衰曲線は完全な勃 起のみられた症例に比較してゆるやかなるのであり，

V.S.S。負荷後の陰茎内血流量 \& $5.8 \sim 16.4 \mathrm{ml} / 100 \mathrm{~g} / \mathrm{min}$ と完全勃起のみられた症例程は多くなかつた。一方勃起 に伴う陰茎内血流量は個人によつてかなりの差（5.8〜 
$57.6 \mathrm{ml} / 100 \mathrm{~g} / \mathrm{min})$ がみられたのは陰茎容皘が個人によ り異なるといらこと, また勃起とのものが情動作用に強 い影響をうけるもので，精神状態や V.S.S. 飞対する反 沁差があること等がその原因と考号られる。

次に V.S.S. 負荷によっても全く勃起のみられなかっ た症例でも全例ともに V.S.S. 負荷後わずかながらも陰 茎内の血流増加がみられることがわかつた。

以上の如く著者の成續では勃起時の陰茎海綿体内の血 流は著明に増加していることがわかつた。このことから 陰茎の静脈系に閍鎖機構がなくとも血液量の著明な増加 があれば十分勃起はおこりらることが考えられた。

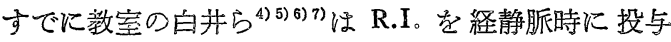
し，勃起時には陰茎内に多量の血液がプールすることを 証明して打り，今回の検査結果と考允合わせると勃起現 象は単なるらつ血によるすのではなく勃起時には多量の 血液が陰茎内に流入すると同時に陰茎内より流出する血 液量も增加するという結論であつた。

\section{結 語}

勃起には何ら異常の認められない症例 8 例とインポテ ンスを主訴とした40例の 陰茎海綿体に Xe-133を注入 し，その減衰曲線から勃起前後の陰茎内の血流動態を観 察した。な和勃起は visual sexual simulation (V.S.S.) を負荷することにより括こさせた。

まず非勃起時の Xe-133減衰曲線は極めてゆるやかで 陰茎内血流量は $0.5 \sim 6.5 \mathrm{ml} / 100 \mathrm{~g} / \mathrm{min}$, 平均 $2.30 \mathrm{ml} / 100 \mathrm{~g} /$ min であつた。また V.S.S. 負荷により完全な勃起のみ られた21例の Xe-133減衰曲線は勃起 ととも急激な $\mathrm{Xe}-133$ 減衰曲線の下降を認め, V.S.S、負荷後の陰茎内 血流量は $15.4 \sim 50.4 \mathrm{ml} / 100 \mathrm{~g} / \mathrm{min}$, 平均 $31.61 \mathrm{ml} / 100 \mathrm{~g} / \mathrm{min}$ で非勃起時に 比較して平均26.17倍の 血流増加がみら
れた。次に勃起が不完全な13例でも V.S.S. 負荷後 Xe133減衰曲線の 著明な下降がみられ，陰茎内血流量は $5.8 \sim 16.4 \mathrm{ml} / 100 \mathrm{~g} / \mathrm{min}$, 平均 $11.90 \mathrm{ml} / 100 \mathrm{~g} / \mathrm{min}$ と非勃 起時に比較して平均11.08倍の血流増加をみた。最後に V.S.S. 負荷により全く勃起のみられなかつた13例では減 衰曲線の下降はみられなかつたが陰茎内血流量は2.7〜 $9.9 \mathrm{ml} / 100 \mathrm{~g} / \mathrm{min}$ (1.1〜 7.6倍) と全例ともわずかながら V.S.S。負荷に血流量の増加がみられた。

以上のことから陰茎の勃起に際して静脈系の閉鎖機構 が存在しなくとも血流量の著明な增加があれば十分勃起 がおこりうるといらことがわかつた。

稿を終るにあたり。御指導を睗つた東北大学宾戸仙太 郎名誉教授。御校閲を睗つた折笠精一教授。また御指導 を仰いた白井将文講師ならびに本学放射線医学教室中村 護講師に深甚なる謝意を表します。また本研究に幾多の 御協力をいただいた福島労災病院泌尿器科千葉隆一博 士, 本学放射線科沢井義一技官ならびに福島労災病院放 射線科小野威夫技官に深謝いたします。なお本論文の要 旨は第22回日本不妊学会総会で報告した。)

\section{文献}

1) Conti, G.: Acta Anat, 14, 217, 1952.

2) Newman, H.F., Northup, J.D. and Devlin. J: J. Inv。 Urol., 1, 350, 1964.

3) 田中敬正：日医放誌，32，425，1972.

4) 白井将文：日泌尿会誌，62，147，1971。

5) 白井将文：日泌尿会誌，64，779，1973.

6) 白井将文:日泌尿会誌，64,786, 1973 。

7) 白井将文, 石井延久, 光川史郎, 中村 護：日 泌尿会誌，68，145，1977.

（1977年12月17日受付） 